\title{
„Bumm a fejbe...", avagy kivégzés és leszámolás a kilencvenes években alvilági módra
}

\section{KOVÁCS István ${ }^{1 \oplus}$ - TORMA Albert ${ }^{2 \oplus}$}

\begin{abstract}
A kilencvenes éveket Magyarországon bizonytalan helyzet jellemezte, amely táptalajt nyújtott a szervezett bünözés térhódításának. Alvilági csoportok gyilkolták egymást, számos ügy a mai napig is bírósági eljárás tárgyát képezi. A tanulmánysorozat tudományos igénnyel vizsgálja azt, hogy vajon az alvilági körökben ismert $D$. Ferenc ellen elkövetett emberölés a vállalkozó árulása miatt történt-e, vagy más indok vezérelte az elkövetöt. A tanulmány a Cinóber ellen elkövetett emberölés büntetöügyének bírósági ítéleteit, szakértői véleményeit elemzi, amelyet nemzetközi színtéren maffialeszámolásokból nyert adatokkal hasonlít össze, értékelve a kettő között fennálló korreláció mértékét.
\end{abstract}

Kulcsszavak: alvilág, kilencvenes évek, szervezett bünözés, rendszerváltás, prostitúció

\section{Bevezetés}

Egy hideg téli napon, 1996. december 18-án a késő délutáni órákban D. Ferenc, az alvilágban „Cinóberként” ismert férfi elhagyta budapesti, Üllői úti lakását és a közelben parkoló gépkocsijához indult. Nem volt könnyú helyzetben, nehéz idők jártak akkoriban az alvilági figurákra. Nem sokkal korábban, közel másfél hónapja ölték meg P. Józsefet az óbudai Ladik utcában, november 13-án L. Csaba ellen követtek el merényletet az ügetőpályán, november 21-én kilenc lövéssel megsebesítették T. Pál vállalkozót.

Most azonban valami szokatlan készülődött, olyan esemény, amely kissé különbözni fog a szinte menetrendszerú merényletek, kivégzések, emberölések egyhangú koreográfiájától. Ahogyan "Cinóber” a sötétben parkoló gépjármüvét megközelítette, sejtelme sem volt arról, hogy figyelik. Figyelik és követik, pár pillanat múlva pedig - eltérően sorstársaitól - megalázó módon, hátulról végeznek vele.

Kovács István PhD, Nemzeti Közszolgálati Egyetem Rendészet Vezetéstudományi Tanszék, tanársegéd, r. őrnagy. István Kovács, PhD, University of Public Service, Faculty of Law Enforcement, Department of Law Enforcement Management Theory, Police Major, Assistant Lecturer. E-mail: kovacs.istvan@uni-nke.hu

2 Torma Albert Dr. med., Dr. jur., r. o. ezredes, Nemzeti Közszolgálati Egyetem Rendészettudományi Doktori Iskola, doktori hallgató.

Albert Torma, PhD, Police Doctor Colonel, University of Public Service, Faculty of Law Enforcement, Doctoral School of Law Enforcement, PhD student. E-mail: albert.torma@gmail.com 
Két lövés halk hangja hallatszott a sötétben, a hangtompítós fegyverek által kiadott, szakavatottak által jól ismert „pukkanásszerú” hangot hallatva. D. Ferenc azonnal meghalt, tekintve, hogy a két lövés a nyak felső szakaszát - a tarkó alsó területét - érte, ahol a golyók a nyaki gerincvelő-sérülés révén a légzőközpont azonnali bénulását idézték elő. Az elkövető nem bízta a véletlenre, fél-egy méter távolságról lőtt és pontosan.

A későbbi információk tükrében „Cinóber” halála önmagában nem lehetett váratlan. A Fővárosi Törvényszék 5.B.609/2013/451. számú ítélete kábítószerrel is kapcsolatba kerülő, prostituáltak futtatásával foglalkozó alvilági figuraként jellemzi, aki azonban nem volt tekinthető az akkori alvilági élet meghatározó szereplőjének. Egyebek mellett valutázással, ékszer-kereskedelemmel, cégtulajdonlással, ingatlanügyletekkel foglalkozott, anyagi helyzete mégis, halálának évében, jelentős hanyatlást mutatott, adott esetben kölcsönöket is kényszerült felvenni alapvető szükségleteinek kielégítésére.

Nem szerencsés az alvilágban anyagi gondokkal küzdő, lecsúszott helyzetbe kerülni, amelyet feltörekvő ambíciókkal jellemezhető személyiségjegyek is súlyosbítanak. Ilyen helyzetben kétségbeesett vagy meggondolatlan lépésre is elszánhatja magát a bűnöző, ami a kilencvenes évek golyózáporában semmiképpen sem volt életbiztosításnak nevezhető. Mindenesetre „Cinóbernek” az akkoriban elhíresült, a prostituáltak nem túl vonzó világáról szóló „K1” című filmben tett átgondolatlan kijelentése, amely szerint olyat tud, amit kevesen tudnak felhasználni, még a szakmában járatlan, kezdő bűnözőknek is fenyegetésként hangozhatott, és a bűnözésben megfáradt, üldözési mániában szenvedő kulcsfigurák pedig kifejezett zsarolásként értékelhették. A kijelentés még csekély értelemű, egyszerű bandatagként sem értelmezhető másként, mint olyképpen, hogy valami olyan jelentős, meghatározó információ birtokában van D. Ferenc, amelyet, ha más nem is, de a bűnüldöző hatóságok értékelni és hasznosítani tudnak.

„Cinóber” kivégzésével kapcsolatban az első fokon eljáró Fővárosi Törvényszék már hivatkozott 5.B.609/2013/451. számú és a másodfokú Fővárosi Ítélőtábla 5.Bf.281/2016/59. számú ítéletében a tanúvallomást tevő személyek által elmondottak érdekes módon mindenre engednek következtetni, csak D. Ferenc esetleges hatóságokkal történő együttmúködésére, köznapi szóval: árulására nem. Ellentmondó információk láttak napvilágot arról, hogy az elhalt kábítószerrel kereskedett, ugyanakkor pénzzel tartozott az e körben érintetteknek, lányokat futtatott, céges ügyletek okán tartozott és talán emiatt kellett meghalnia, akad olyan tanú is, aki a kábítószer szerepét, más tanú pedig a tetemes tartozást kétségbe vonta. Összességében a rendelkezésre álló dokumentumok alapján nem állapítható meg, hogy D. Ferencnek valójában pontosan miért is kellett meghalnia azon a téli napon.

Ugyan a szervezett bűnözés jellege transznacionalitását tekintve egyes országokban - a csoportok dinamikája, összetétele, felépítése, normarendszere, társadalmi beágyazódása - eltérő lehet, érdemes megvizsgálni, hogy azok milyen különbségeket és hasonlóságokat mutatnak. Hosszas szakirodalmi kutatás során 
a szerzőpáros rábukkant egy olyan esetre, amely a tarkólövést az alvilági körökben árulásért járó büntetéssel azonosítja. A büntetett előéletű Mariano Bacio Terracino például 2009. május 11-én éppen a nápolyi, sokat mondó elnevezésű Vergini (Szűzek) bár előtt szívta a cigarettáját, amikor baseballsapkás gyilkosa hátulról rálőtt, majd tarkólövéssel végzett az áldozattal - ahogyan a nápolyi maffia, a Camorra belső szabályai előírják a teendőket árulással érintett bandatag esetére. ${ }^{3} \mathrm{Az}$ esetet kamerafelvétel rögzítette, a tettes nyugodtan sétált el, ami szemtanúk szerint az egész eseményt még inkább félelmetessé tette. A fentiekből adódik a kérdés: vajon mennyiben tér el, vagy mennyiben hasonlít Cinóber meggyilkolása a fenti esethez?

D. Ferenc meggyilkolásának számos oka lehetett, amelyet az ügyben folyó büntetőeljárás próbált felgöngyölíteni, azonban az adatok alapos áttanulmányozása sem ad megnyugtató választ arra a kérdésre, végül is miért kellett az alvilági életben nem kiemelkedő szerepet játszó, befolyásosnak nem nevezhető áldozatnak meghalnia. A kivégzés módja az előzmények tükrében, a merénylet ideje (kora esti órák), az eset összes körülménye összességében nem zárja ki annak a lehetőségét, hogy „Cinóber” kivégzésével üzenetet közvetített az alvilág azoknak, akik anyagi helyzetüket, alvilági pozíciójukat, befolyásukat árulással, a hatóságokkal történő együttműködéssel kívánják bebiztosítani, mint ahogyan azt a későbbi események - 1998. július 2-i Aranykéz utcai robbantás - is alátámasztják.

A fenti tanulmányban a szerzők azt vizsgálják, hogy a „Cinóber” ellen irányult kivégzés vajon valóban amiatt történhetett-e, hogy az éjszakában „rendőrspiclinek” vagy „susogónak” is nevezett D. Ferenc alvilági besúgó volt, amelyet az akkori szervezett bűnözői csoportok megelégeltek, vagy sem. A felállított hipotézis szerint feltételezzük, hogy a halotti szemle jegyzőkönyvéből és a szakértői véleményekből nyert adatok, valamint az alvilági „árulásért” végrehajtott kivégzések között korrelációs kapcsolat van, amely arra enged következtetni, hogy az árulás búnébe esett alvilági embereket Magyarországon is - csakúgy, mint Olaszországban - kivégzésszerűen ölik meg. De facto ebből következésképpen az is feltételezhető, hogy a kivégzésszerú ölés utalt az áldozat árulására is. A hipotézis tesztelésére a szerzők primer és szekunder források elemzését, analízist és szintézist, forráskritikát, valamint ítéletelemzést hajtottak végre. Mindennek vonatkozásában megjegyzendő, hogy a tanulmány a fentieket kizárólag tudományos igényességgel kívánja vizsgálni, a szerzők a bírósági ítéletekben az elkövetők motívuma mellett/ellen nem kívánnak érvelni. 


\section{„Az egész magyar alvilág megbolondult...", ${ }^{4}$ avagy leszámolások a kilencvenes években}

A rendszerváltást követően jelentkezett az a probléma hazánkban is, mint a többi érintett ország tekintetében, hogy a kezdeti évek során felbomlott a régi jogrend, és a helyébe lépő új rendszer még nem alakult ki megfelelően, ezért nem álltak rendelkezésre a szervezett bűnözés kezeléséhez szükséges hagyományok és tapasztalatok, így az különösen kedvező táptalajt talált magának a fejlődésre. A rendszerváltás hajnala (leginkább az új berendezkedés ismeretlensége, illetve a teljesen idegen és szokatlan játékszabályok miatt) tele volt bizonytalansággal és ezt számos személy, csoport azonnal ki is használta. Ennek lett egyik következménye, többek között a bűnözés gyors elterjedése is. Ennek eredményeképpen a 20. század utolsó évtizede alatt kiirthatatlanul és elpusztíthatatlanul megvetette a lábát Magyarországon a szervezett bünözés.

A rendszerváltás mint történelmi fordulópont kedvezett a bűnözésnek. ${ }^{5} \mathrm{Az}$ addigi kommunista szemléletű állami berendezkedés végrehajtó hatalmaként funkcionáló „pártöklű” rendőrség az 1980-as évek végére hatalmi pozícióját elvesztette, nagymértékben elbizonytalanodott. A vezető tisztviselők a bizonytalanság által övezett, robbanásig feszült helyzetben képtelenek voltak arra, hogy ezt az időszakot reformokkal, szabályozással és irányítással ellenőrzésük alatt tarthassák. Azt sem tudták, hogy a változás után mi következik, a döntések iránti felelősséget senki sem akarta vállalni, így a rendőrség is várakozó álláspontra helyezkedett. Ez hamar tudatosult a bűnözőkben is, a korábbi számadatokhoz viszonyítva egekbe szökött a vagyon elleni, a személy elleni bűncselekmények száma, az utcákat és a szórakozóhelyeket elöntötték a szerencsejáték-automaták, a prostituáltak, a dílerek és az olajozásból, valutázásból és egyéb jogellenes cselekményekből meggazdagodni kívánó bűnözők százai. A közbiztonsági viszonyok romlottak, a lakosság félelemben élt, a bűnüldöző és igazságszolgáltató szervek pedig reménytelennek tűnő küzdelmet folytattak a társadalmi béke helyreállításának érdekében. ${ }^{6} 1966$ és 1975 között átlagosan az ismertté vált bűncselekmények száma 118 358, a 10 ezer lakosra jutó ismertté vált bűncselkemények száma 115, az ismertté vált bűnelkövetők száma 84 708, az ismeretlen elkövetők száma 21 528-ra nőtt. 1976 és 1985 között ugyan ezen adatok jelentős növekedést mutattak, az ismertté vált bűncselekmények

\footnotetext{
J. Roháč utolsó szó jogán tett vallomása 2016. március 29-én a Főváros Törvényszéken.

Vö.: „A hozzáértők számára a kommunizmus bukása az 1980-as évek második felében már nem volt ugyan kérdéses, a rendszerváltások váratlan mivolta és hirtelen lefolyása mégis meglepetés erejével hatott." Deák József: A Belügyi Szemle és az ideológiai háború Helsinkitől a rendszerváltásig (1975-1990). In Parádi József (szerk): Ünnepi parergák Boda József 65. születésnapja tiszteletére. Budapest, Szemere Bertalan Magyar Rendvédelemtörténeti Tudományos Társaság, 2018. 27; A rendszerváltozás utáni bűnözés alakulásával és annak okaival kapcsolatban lásd bővebben Mátyás Szabolcs: Magyarország általános bűnözésföldrajzi helyzete. Hadtudományi Szemle, 10. (2017), 4. 497-505; Ürmösné, Simon Gabriella: Organised crime. In Gabriella Ürmösné Simon: Technical English for officers. Budapest, Dialóg Campus, 2018. 87-100.

6 Gönczöl Katalin: A bűnözés és a bűnmegelőzés Magyarországon a rendszerváltás időszakában. Magyar Jog, 38. (1991), 11. 646-653.
} 
száma 20 ezerrel, az ismert elkövetők száma több mint 15 ezerrel emelkedett. 1990-re 341061 ismertté vált bűncselekményről, 113330 ismeretlen elkövetőről volt tudomásunk, amely így a 10 ezer lakosra jutó ismertté vált bűncselekményi számot több mint háromszorosára, 326-ra növelte. ${ }^{7}$ Elmondható viszont, hogy a bűnözés volumene a társadalomban indikátorként is megjelenik, az tükrözheti a társadalom aktuális állapotát, amely a gazdasági és politikai életre is kiterjed.

A prostitúcióból, az olajozásból, a valutázásból befolyt összegekért megindult a leszámolás. Oroszok, ukránok, albánok, szlovákok és magyarok kezdték gyilkolni egymást. (A különböző esetek elemzéséhez a szerzőknek az ítéleteken és más szakirodalmi forrásokon kívül nagy segítséget nyújtott a magyar szervezett alvilág őstörténete cikksorozat is, amely kronológiailag helyezi el az eseményeket. ${ }^{8}$ ) Az elsők között szereplő orosz leszámolás 1994. március 3-án volt, amikor a sármelléki repülőtéren egy IL-76 típusú szállítógép felrobbant. A repülő az Ural Air Company tulajdonában állt, az ügyvezető N. Sirokov volt. Ô volt a Magyarországon aktívan tevékenykedő jekatyerinburgi maffia első számú embere testőrségének vezetője. Sirokov cégeket alapított és dollármilliókat szerzett az olajozásból. Feltehetően ez sérthette a konkurens ukrán érdekeltségeket, mert 1993. év december 3-án Budapesten, a II. kerületi Virág Benedek utcában meggyilkolták, életét még testőre R. Valejev sem tudta megmenteni. A lehetséges elkövetők között merült fel Sz. Gorbunov neve, akit néhány nappal később Húvösvölgyben találtak meg fejbe lőve. Ezen időszakban nemcsak az oroszok, de a magyar bűnözők is gondoskodtak egymás likvidálásáról.

A nagy értékű illegális és lopott gépkocsik kereskedelmének köszönhetően R. László és Cs. Zsigmond 1990. év nyarán megalapította a Conti Car cégcsoportot. 1992. év közepén S. Jánost, a cég üzlettársát brutális kegyetlenséggel meggyilkolták. Itt lépett a képbe B. József, akit médiaszereplései révén csak Tamásként ismerhetünk. Ô R. László távoli rokona, építési vállalkozó, de szerette volna kivenni a részesedését az illegális tevékenységekből is. Kisebb jogsértések elkövetését követően a hatóság a 1995. szeptember 19-én, Budapesten a VIII. kerületben a Práter utcában történt robbantásos búncselekmény elkövetésével hozta összefüggésbe, ám mindösszesen 30 nap előzetes letartóztatás után szabadult. Az áldozat N. Awad volt, egy Jordániából bevándorolt és áttelepült pénzváltó, aki a valutából adódóan magas kamatra tett szert, pénzének nagy részét pedig uzsorakölcsönökbe fektette. Neve összemosódik a Balkán útvonallal kapcsolatos kábítószer-kereskedelemmel is, meggyilkolásának indítékai között szerepelt a megrendelőnek szállított rossz minőségú kábítószer is. 1997. év elejére B. Tamás kapcsolata megromlott a cégcsoport vezetőségével, és ismeretlenek megpróbálták solymári házában megölni. Neve a hatóságok előtt ebben az időben válik ismertté, ugyanis egy nyomozási alku keretében videóvallomásban beszélt alvilági kapcsolatairól, a bűnözők illegális profitszerzési lehetőségeiről és módjairól, valamint a szervezett bűnözés és az állami vezetés összefonódásáról.

\footnotetext{
Gönczöl Katalin: Szegénység és bűnözés. INFO-Társadalomtudomány, 5. (1991), 16. 25-30.

Heti Válasz: A magyar szervezett alvilág őstörténete 1-10. Válasz.hu, 2012.
} 
Mindennek eredményeképpen 1997 áprilisában R. Lászlót és Cs. Zsigmondot a hatóságok letartóztatták. Nevezettek mellett jelentős szerepet kapott T. György is, aki azzal vívta ki magának a tiszteletet, hogy fel tudott lépni a különböző szervezett búnözői csoportok és érdekeltségek ellen, az alvilág végrehajtója nem válogatott a módszerek közül, véreskezű, erőszakos ember volt. Jól mutatja ezt bűnlajstroma is, amely különböző bűncselekményekból és bírósági ítéletekből tevődik össze: példának okáért lásd a PKKB 3.B. IX. 80.068/2010/186. számú, illetve a Fővárosi bíróság 24.Bf. 8766/2011/6. számú 2011. november 17. napján jogerős ítéletét zsarolás büntett elkövetése miatt; vagy a Pesti Központi Kerületi bíróság 2017. január 17. napján kelt 7.B. 30.677/2016/89. számú határozatát önbíráskodás bűntettének kísérlete, folytatólagosan társtettesként elkövetett garázdaság büntette, testi sértés bűntettének kísérlete, kábítószer birtoklásának vétsége stb. miatt.

Mindezzel párhuzamosan 1992-ben a Pest Megyei Rendőr-főkapitányság zsarolás és más bűncselekmények megalapozott gyanúja miatt nyomozást rendelt el P. József, Cs. Attila és T. Péter ellen.

P. József neve azért jelentős, mert meggyilkolása után bontakozott ki az igazi bandaháború. Nevezett éppen terepjárójába szállt be 1996. november 1-jén, az óbudai Ladik utcában, amikor egy motorkerékpáros állt meg mellette, nevén szólította, majd közvetlen közelről fegyverrel fejbe lőtte. Az indítékok között egy kölcsönösszeg meg nem fizetése, valamint anyagi elszámolási vita áll. P. József társa, Cs. Attila szerencsésebb volt, ő egy szamurájkarddal végrehajtott támadás során „csak” életveszélyesen sebesült meg. A támadással kapcsolatban T. György neve merült fel mint elkövető, de Cs. Attila nem múködött együtt a hatósággal a nyomozás során. Operatív forrásokból ismert volt a cselekmény valamennyi momentuma, de ez nem volt elegendő a sikeres bizonyításhoz. T. György is túlélt már támadást, amikor saját tulajdonú gépjárművét szitává lőtték.

A merénylet után néhány nappal, 1996. november 21-én, Budapesten, a II. kerületi Pipitér utcában kilenc lövéssel megsebesítették T. Pál vállalkozót. Nyolc nappal később Budapesten, az I. kerületi Attila út 13. számú ház előtt egy támadó rálőtt D. Sándor kaszinótulajdonosra. Z. Gyula is az áldozatok között van, akinek terepjárója alatt 1997. május 5-én robbant bomba. Mindannyiukban közös, hogy tulajdonukban számos éjszakai bár, masszázsszalon, szórakozóhely állt, amely nyíltan közvetített prostitúciós és kábítószerrel kapcsolatos szolgáltatásokat. Mindenki azt szerette volna, ha egyeduralkodóként van jelen a piacon.

B. Tamás 1998. július 2-án leparkolt az Aranykéz utcai parkolóházban és elindult az évek óta szokásos útvonalán a közelben lévő irodája felé. Amikor dél magasságában egy az utcán parkoló kis Polski mellé ért, a benne korábban elhelyezett bombát az elkövetők működésbe hozták és felrobbantották. A nagyjából négykilónyi TNT-nek megfelelő erejű robbantás hatalmas pusztítást végzett; a vállalkozóval együtt négy ember életét vesztette, és több mint 20 személy sérült meg. Az elkövetéssel már akkor meggyanúsították J. Roháčot és szlovák társait, akikről kiderítették, hogy a Béke Hotelben készültek a támadásra, a bombát is ott „pihentették” mielőtt beépítették volna a merénylethez használt kis Polskiba. Az autót J. Hamala vásárolta álnéven, hamis 
papírokkal. A technikai fejlettségnek köszönhetően az ezzel kapcsolatos büntetőper ma is zajlik - perújítás -, ahol végül P. Tamást hozták kapcsolatba a felbujtói magatartással.

1999. február 2-án Budapesten, a XV. kerületben a Szent Korona utca 25. szám alatt egy bérgyilkos kivégezte az akkoriban éppen börtönbüntetését töltő, s onnan eltávozásra kiengedett D. Györgyöt és testőrét. Alig két hónappal a Szent Korona utcai leszámolás után, 1999. április 12-én Tahitótfaluban rálőttek S. Zoltán Bentley-jére, amely nagy sebességgel a falhoz vágódott. S. Zoltán a helyszínen életét vesztette. 1999. április 19-én kézigránát robbant Szentendrén, és könnyebben megsebesítette Cs. Zsigmondot, a Conti Car egyik alapító tulajdonosát. 1999. június 11-én este bomba robbant a X. kerületben a Kőér utcai Spartacus sporttelep büféje előtt, amelyet gyakran látogattak a S. Zoltánhoz közel álló személyek. Ugyanazon a napon a 20. kerületben meglőtték Cs. Barnabást, aki akkoriban egy őrző-védő cég mellett a Spartacus sportboltot is múködtette.

A millenniumot követően „mintha elvágták” volna a merényleteket és robbantásokat. Az erőszakot és a hatalmi átrendeződést felváltotta a látencia és az operatív múködés. Ugyanakkor kijelenthető, hogy a szervezett bünözés a mai napig az életünk szerves részét képezi - 2020-ban is vannak olyan büntetőeljárások, amelyek e cselekmények felderítésével és bizonyításával foglalkoznak. Ilyen például a tanulmányban vizsgálni kívánt D. Ferenc, azaz „Cinóber” elleni merénylet is.

\section{„Cinóber" kivégzése}

A Fővárosi Törvényszék az 5.B.609/2013/451. számú ítéletében „Cinóbert” úgy jellemezte, mint a kilencvenes évek budapesti alvilágának tagját, aki prostituáltakat futtatott, kábítószerrel is kapcsolatba került, azonban sosem számított igazán nagystílú bűnözőnek, az éjszakai élet meghatározó alakjának. Több cégben rendszeres ellenszolgáltatásért tulajdonos volt (amely mögött valós tulajdoni viszonyok valójában nem álltak), így a prostitúció, a valutázás és az ékszerkereskedelem mellett ez számára megfelelő forrású jövedelemkiegészítést jelentett. Annak ellenére, hogy a fenti tevékenységek kiemelkedően jövedelmeztek, könnyelmúen bánt a pénzzel, így 1996-ra anyagi helyzete jelentősen megromlott, előfordult, hogy saját lakásának rezsijét sem tudta kölcsön nélkül kifizetni.

Az éjszakában suttogók szerint viszont - ahogy akkor a legtöbben - „Cinóber” ingatlanügyletekből és az „olajozásból” is szerette volna kivenni a részét, amely olyan csoportok érdekeit sértette, akik e fekete üzletág akkori egyeduralkodói voltak. ${ }^{9}$ Mindezt úgy kívánta elérni, hogy a birtokában levő információkkal e köröket zsarolja. Ezt megerősíteni látszik, amikor a K2 címú prostituáltakról szóló dokumentumfilmeben önmagáról úgy

\footnotetext{
Kovács István: „Olajozás”, szervezett bünözés és prostitúció a 90-es években Magyarországon. Nemzetbiztonsági Szemle, 3. (2015), 1. 114-145; Kovács István: Magyarország határain átnyúló szervezett bűnözés és prostitúciós bűncselekmények a schengeni térségben, különös tekintettel a SOCTA és EUROSTAT értékelésére. Határrendészeti Tanulmányok, 14. (2017), 4. 82-167.
} 
nyilatkozik, mint aki „minden titkok tudója”. ${ }^{10}$ Az említett dokumentumfilmben például sikeres lányfuttatóként ismerhetjük meg, aki a szerepléséért 100 ezer forint mellékjövedelmet tudhatott magáénak.

Bármelyik arcát is mutatta valójában, a végzetét ő sem kerülhette el. 1996. december 18. napján az Üllői úti lakása előtti parkolóban egy 7,65 mm kaliberü fegyverrel közvetlen közelről két lövéssel végeztek vele. D. Ferenc sérelmére elkövetett emberölés vonatkozásában - valamint összevont másik három tényállásban; amelynek ismertetésére ebben a tanulmányban nem kerül sor - a nyomozó hatóság négy főt gyanúsított meg, az ügyészség pedig négy fő ellen emelt vádat, különböző eljárásjogi minőségben. (Elkövető, felbujtó, bűnsegéd stb.) Az I. rendű vádlott J. Roháč mint elkövető, II. rendű vádlott L. Trnka mint bűnsegéd, a felbújtók pedig P. Tamás III. és F. Attila IV. rendú vádlottak voltak. (Ezen eljárásjogi pozíciók az ítéletekben 1-4. pontokat lefedő tényállásokban realizálódtak, a „Cinóber” elleni emberölés körülményeit a 4. tényállási pontban rögzítettek tartalmazták. Minderre azért kerülhetett sor, mert a Fővárosi Főügyészség 2013. március 12-én, 2014. szeptember 2-án és a 2015. június 29-én benyújtott vádirata alapján indított büntetőeljárásokat a Fővárosi Törvényszék egyesítette.) Számunkra viszont kizárólag a 4. tényállási pont releváns, mert a D. Ferenc sérelmére elkövetett emberölés vonatkozásában a hipotézis vizsgálatának tárgyát az képezi.

A Fővárosi Törvényszék mint első fokon eljáró bíróság 5.B.609/2013/451. számú ítéletében, a 4. tényállási pontban szereplő és felvonultatott körülmények és bizonyítási eszközök alapján:

- I. rendú vádlottat az ellene a régi Btk. 166. § (1) bekezdésébe ütköző és a (2) bekezdés $a)$ pontja szerint minősülő emberölés bűntette;

- III. rendû vádlottat a régi Btk. 166. § (1) bekezdésébe ütköző és a (2) bekezdés a) pontja szerint minősülő felbujtóként elkövetett emberölés bűntette;

- IV. rendű vádlottat szintén a régi Btk. 166. § (1) bekezdésébe ütköző és a (2) bekezdés a) pontja szerint minősülő felbújtóként elkövetett emberölés bűntette miatt emelt vád alól felmentette.

A Fővárosi Ítélőtábla mint másodfokú bíróság az 5.Bf.281/2016/59. számú ítéletében az elsőfokú bíróság ítéletét részben megváltoztatta, míg az ítélet egyéb törvényes rendelkezéseit helybenhagyta. (Differenciáltan az 1-4. tényállási pontok tekintetében. A 4. tényállási pontban foglaltakat helybenhagyták. $)^{11}$

Az ügyben készült első rendőri jelentésből megállapítható, hogy 1996. december 18-án 18 óra 55 perckor az Üllői úthoz közel eső aszfaltos járdán egy személygépkocsi mögött egy háton fekvő, vérző férfit találtak, akihez mentőt hívtak. A mentőorvos

10 E filmben, az egyik jelenetben „Cinóber” és egy prostituált arról beszélgetnek, hogy névtelen bejelentés alapján a rendőrség akár fél év időtartamban is kivonhatja a lányt a munkából, amelyet „Cinóber” kapcsolatai és pozíciója révén 72 óra, vagy maximum 1 hónap időtartamra akár le is tud csökkenteni. Szövegkörnyezet: „Ezt csak én tudom elérni. Hát... sajnos olyan... hogy is mondjam? Nem a presztizsem, nem a respektem, hanem olyat tudok, amit kevesen tudnak felhasználni." Forrás: www.youtube.com/watch?v=pCjWVSKFXTM

11 Kovács István: Azok a 90’-es évek: prostitúció és szervezett bűnözés, különös tekintettel a „Cinóber” sérelmére elkövetett emberölésre. Magyar Bünüldöző, 11. (2020), 1-2. 100-113. 
megállapította, hogy a férfi bal oldali, fül alatti nyakrészénél két, a jobb oldalinál egy, feltehetően lövéstől származó seb volt látható. Ezen túlmenően a mentőorvos már csak a halál beálltát tudta megállapítani. A helyszíni szemle jegyzőkönyve és a hozzá tartozó fényképmelléklet a fenti rendőri jelentésben foglaltakkal azonos adatokat tartalmaz, és megállapítható belőle, hogy a sértettnél és a gépkocsijában különböző tárgyakat, így egy csomag aranyékszert és egy csomag kábítószergyanús anyagot is találtak, amelyet bünjelként foglalt le a nyomozó hatóság.

A rendőrorvosi halottszemle jegyzőkönyvéből azt lehet megállapítani, hogy a halál 18 óra 45 körül, idegenkezúség következtében állhatott be. Az időpont megegyezik a rendőri jelentésben írt bejelentés időpontjával. A halottszemléről készült jegyzőkönyv és fényképmelléklete, valamint a két igazságügyi orvosszakértő által készített boncjegyzőkönyvbe foglalt igazságügyi orvosszakértői vélemény szerint a sértett halála erőszakos úton, a bent rekedő lövési sérülés miatt létrejött nyaki gerincvelő-rázkódás következtében kialakult légzőközpont-bénulás, légzésbénulás során jött létre. Az elszenvedett sérülés és a halál között közvetlen okozati összefüggés áll fenn. A halál azonnali volt, a sértett életét azonnali, szakszerű orvosi beavatkozás sem tudta volna megmenteni. Olyan idült belső szervi elváltozásokat, amelyek elősegítették volna a halál beálltát, nem észleltek, és megállapították azt is, hogy a bemeneti nyílások területén közeli lövésre, vagy rászorított csővel történő lövésre utaló elváltozásokat nem találtak. Ennek alapján, amennyiben a sérüléseket maroklőfegyverrel okozták, a lőtávolság nem lehetett rövidebb fél-egy méternél. A nyomozó hatóság a nyomozás továbbfolytatásakor a halálok tekintetében újabb igazságügyi orvosszakértői vélemény készítését rendelte el. A szakértők az eredeti boncjegyzőkönyvben foglaltnál részletesebb, de a lényegét tekintve azzal megegyező tartalmú szakvéleményt adtak.

A fenti rendőri jelentésből, valamint az orvosszakértői véleményből D. Ferenc kivégzésével kapcsolatban az alábbiakat lehet megállapítani:

- az emberölésre nem fényes nappal, mindenki szeme láttára, hanem az esti órákban, egy utcai övezetben, parkoló gépjármúvek között került sor;

- az elkövető egy 7,65 mm kalibernek megfelelő maroklőfegyverrel vagy pisztollyal, géppisztollyal több lövést is leadott, amelyből megállapítható volt, hogy közeli lövésre vagy rászorított csővel történő lövésre utaló elváltozásokat nem keletkeztetett;

- a lőtávolság nem lehetett rövidebb fél-egy méternél, azaz közvetlen közelről történt;

- D. Ferenc bal oldali, fül alatti nyakrészénél két-, a jobb oldalinál egy lövéstől származó seb volt látható, amely egyértelműen arra utal, hogy az elkövető nem szemből, hanem oldalról vagy hátulról tüzelt;

- „Cinóber” halála erőszakos úton, a bent rekedő lövési sérülés miatt létrejött nyaki gerincvelő-rázkódás következtében kialakult légzőközpont-bénulás, légzésbénulás során jött létre, életét szakszerű beavatkozás sem tudta volna a helyszínen megmenteni, azaz az elkövető biztosra ment a több lövés leadásával. 
A fentiek arra engednek következtetni, hogy „Cinóber” alvilági leszámolás áldozata lett, amelyet a következő fejezetben nemzetközi színtérrel, alvilági leszámolásokkal, különös tekintettel az alvilági „árulók” kivégzésével vetünk össze.

\section{Dante és a kilencedik kör: az árulók bünhödésének helyszíne, ${ }^{12}$ avagy kivégzés az alvilágban}

Nem kizárólag gengszterfilmekben láthatjuk, hogy az árulókat mindig hátulról lövik le, hanem a szervezett bűnözéshez köthető alvilági csoportoknak és felbérelt bérgyilkosoknak is kedvelt módszere ez a kivégzési rituálé. Mindez köthető a világ egyik legismertebb szervezett bűnözői csoportjához a Cosa Nostrához is, amelynek ítélete szerint „véreddel lépsz be, véreddel is távozol”, illetőleg a „papírként égetlek, szentként imádlak; ahogy ez a papír ég, úgy a húsomnak is égnie kell, ha elárulom a Cosa Nostrát" ${ }^{13}$ Általános szabályként érvényesül, hogy a szicíliai kultúrában a „zümmögés, ciripelés, csicsogás” kardinális bűnnek számít. A Cosa Nostra, avagy a „csend kódjának” megtörőit az alábbi szinonimákkal is illették: áruló, kanári, mélytorok, patkány, besurranó, szajkózás, forrás, csiklandozó, csörgő. ${ }^{14}$ Minden szervezett bűnözői tag tudja, hogy az árulást a szervezetben halállal fizetik. ${ }^{15}$

M. Avola hírhedt szicíliai bérgyilkos volt, aki több mint 80 emberrel, közöttük az egyik legjobb barátjával is végzett, mert elárulta a szervezetet. Egy vele készült interjúban az alábbiakat nyilatkozta: „P. di Leo. Ő volt az egyik legjobb barátom. Megparancsolták, hogy oltsam ki az életét. Túl sokat tudott, és azzal gyanúsították, hogy elárulta a Családot. Kénytelen voltam lelőni. Még mindig rémálmaim vannak róla minden este, valamint a többi férfival kapcsolatban, akiket megöltem. Éjjel kísértenek." ${ }^{16}$ Az éjjeli, esti időpont ezen idézett résznél például kardinális elem.

R. Messina a Savasta klán tagja volt, szövetségben áll a hatalmas Cosa Nostra családdal, élén N. Santapaolával, Cataniában. R. Messina úgy döntött, hogy kiszáll a maffiából, és együttmúködött a hatóságokkal, tanúvallomást tett. Messina egykori klánjának maffiózói fenyegetni kezdték feleségét Lilianát, aki a fenyegetésekről beszámolt az ügyészeknek is. Napokkal később, Liliana és édesanyja a szokásos reggeli élelmiszerboltjukban vásároltak. A boltban egy kivégzőosztag várta őket, ahol négy maffiózó kifejezetten Lilianát vette célba, többször meglőtte, főleg az arcába hogy elcsúfítsák azt. Felkutatták az anyját is, aki parkoló autók közé rejtőzött, és megölték ôt is. A támadást

12 Dante Alighieri: Isteni színjáték. Budapest, Akkord, 2009.

13 Giuseppe Falcone: Cose di Cosa Nostra. Rizzoli, 1991; Procura Della Repubblica di Palermo: Direzione Distrettuale Antimafia. Verbali di Interrogatorio reso dal collaboratore di giustizia, Leonardo Messina. Judical Document. 1992.

14 Adriana Nicole Cerami: The Mafia's system of silence in communication, film and literature: Perversions of society and transgressions of Omertà. Chapel Hill, University of North Carolina, 2009.

15 Juan Carlos Garzón: The criminal networks in Mexico, Brazil, and Colombia. WWIC, 2008.

16 Lorenzo Tondo: Meet the Sicilian mafia hitman who killed 80 people and will be free in 5 years. Time, 2015. 10. 21. 
Messina Cosa elárulásának vendettájaként követték el, de üzenetként szolgált, hogy hagyjon fel a törvénnyel való együttműködéssel is. ${ }^{17}$

1994. április 8-án a leszámolások célpontja A. Alfieri volt. A Camorra csapata meg akarta ölni Alfierit, mert az apja elárulta a maffiát, de nem volt otthon, amikor a bérgyilkosok rájuk törtek az otthonukban, és ezért álmukban családtagjaival, köztük feleségével és három gyermekével végeztek, mindannyiukat hátulról, ágyukban érte a halál. Mindezt neki és másoknak szóló figyelmeztetésként szánták, hogy a hatóságokkal való együttmúködésért milyen árat kell megfizetni. ${ }^{18}$

Egyes bűnözők képesek betartani ezt az életformát. A hírhedt D. Brasco ügyben S. Black volt az áldozat. Ő mutatta be olyan főnököknek a fedett nyomozót, mint S. Trafficante Tampában, vagy F. Balistrieri Milwaukee-ban. Elárulta a maffiát azzal, hogy egy spiclit vitt be közéjük, még akkor is, ha akaratlanul tette. S. Blacket szerették volna a tanúvédelmi programba bevenni, de ő megtagadta az erre irányuló felkérést. Mikor Blacket hívatták, tudta, hogy meg fogják ölni, az irodában hátulról kivégezték. ${ }^{19}$

1929. május 7-én Capone partit rendezett Giunta tiszteletére, ahová meghívta két emberét is, Anselmit és Scalise-t. A banketten Capone azzal vádolta meg őket, hogy elárulták őt. Anselmit és Giuntát hátulról leütötte és addig ütötte őket, míg életveszélyesen meg nem sebesültek. Anselmiben még volt annyi lélekjelenlét, hogy ránézett Caponéra és életéért könyörgött: „Nem én, Al. Az ő ötlete volt, én nem tenném.” De Caponét ez sem érdekelte, mindannyiukat hátulról fejbe lőtte. ${ }^{20}$

A maffia alattomos világában kevés szereplő élete bizonyult rövidebbnek, mint F. „Bomp” Bompensierónak. Bomp egyúttal könyörtelen gyilkos és egy FBI-informátor volt, aki elárulta barátait és a családot az FBI-nak. 1977 februárjában ôt is elérte a végzet, amikor egy nyilvános telefonfülkében éppen újabb információkkal szolgált volna az alvilágról, egy ismeretlen fegyveres utolérte, és hátulról négy golyót eresztett a fejébe a hangtompítóval felszerelt automata pisztolyából. ${ }^{21}$

A nemzetközi színtéren végzett kutatás alapján megállapítható, hogy a szervezett bűnözés az árulókat a legsúlyosabb formában likvidálja, megöli:

- a szervezett bűnözés a „csend kódjának” is fordítható, azaz a „zümmögőket”, árulókat a szervezet tagjai kivégzik, más megoldás elhallgattatásukra nincs, amelytől még a tanúvédelmi programok sem menthetik meg teljes bizonyossággal a „susogókat";

- a kivégzések folyamatosak, leginkább gyorsan végrehajthatók, azokat pisztollyal, géppisztollyal követik el közvetlen közelről a cél elérése érdekében;

- az emberölések a vizsgált esetekben nem nappal, hanem este, az éjszaka leple alatt történnek;

\footnotetext{
Robin Pickering-Iazzi: Dead silent: Life stories of girls and women killed by the italian mafias, 1878-2018. French, Italian and Comparative Literature Faculty Books, 2019.

18 Pickering-Iazzi (2019): i. m.

Carl Sifakis: The Mafia Encyclopedia. New York, Checkmark Books, 2005.

Sifakis (2005): i. m.

Sifakis (2005): i. m.
} 
- gyakori elem, hogy a célszemély közvetlen hozzátartozóit is megölik, vagy azok kivégzésével üzennek a célszemélynek, akiket a legjobban szeret, akiket leginkább közelebb érez magához;

- lényeges elem, hogy a halálesetekben közös, hogy több golyóval végeztek az áldozatokkal, azok pedig mindig hátulról vagy oldalról érték az áldozatokat.

\section{Az összehasonlítás eredménye és következtetések}

A nemzetközi színtéren vizsgált árulássorozatok és kivégzések hasonlóságot mutatnak a D. Ferenc ellen elkövetett emberölés vonatkozásában is, de nem korrelálható azok együtthatója. A szerzőpáros centrális elemnek tekinti és hasonlóságnak tárja fel a kivégzés azon módszereit, amelyeket mindig közvetlen közelről, általában kis méretú és kis kaliberü lőfegyverrel követnek el, úgy, hogy az emberölés áldozatát oldalról vagy hátulról éri a halálos lövés. Az elkövetők biztosra mennek azzal, hogy nem egy, hanem több lövéssel végeznek az áldozatokkal. Ugyancsak hasonlóság, hogy mindannyian valamely bünszervezet tagjai voltak, és az esetek többségében bizonyosodott, hogy az áldozat a hatóság informátora, spiclije, besúgója vagy adatközlője volt. Mindannyian vétettek a különböző szervezett bűnözi hálózatok kódexei ellen, megszegték a legfontosabb intézmény egyikét: a hallgatásét. (Ez még akkor is megállapítható, ha a szervezett búnözés jellege a különböző országokban eltérő dinamikát mutat. A konspiráció koherens elem a szervezett bűnözés tekintetében, bármelyik definíciót is vesszük alapul.) Ugyan nem feltétlenül éjszaka, de a kivégzések nagy része az esti, késő esti órákban ment végbe. A helyszínek között is van hasonlóság, több esetben parkoló, utca és nyilvános hely volt a kivégzés helyszíne. A nemzetközi színtér és a hazai vizsgált eset közötti különbség többek között abban is kibontakozott, hogy a D. Ferenc ellen elkövetett emberölés, vagy bármely a kilencvenes években történt merényletsorozatban kizárólag a bünszervezetek tagjai haltak meg, családtagjaik ellen nem irányultak támadások. Jó példa erre, hogy Cinóber élettársa volt például, aki a helyszínen a holttestet azonosította, atrocitás oot sose érte.

Az esetek vonatkozásában megállapítható, hogy a szervezett bünözés látens világa köbe vésett szabályokra és törvényekre épül, amelyeket minden tagnak be kell tartania ahhoz, hogy a szervezet életben maradhasson. Akik a szabályok és a hallgatás ellen vétenek, a legsúlyosabb árral fizetnek: az életükkel. Drasztikus megoldásnak túnik, és egyik bűnözői hálózat sem egyforma, de közös bennük, hogy az árulásért a tagok életükkel tartoznak. (Gondolhatnánk például a Japánban tevékenykedő jakuzára, ahol a tagok bűnbocsánataikért testrészeik - leginkább ujjuk - levágásával fizetnek, de a szeppuku, avagy az öngyilkosság is lehet a fizetség is egyben. A szeppuku végrehajtása tiszteletet feltételez, az árulást ott is a legszigorúbban büntetik.)

A következtetések vonatkozásában szót kell ejtenünk a már említett tiszteletről is. A bủnbandák vonatkozásában a tagok közötti hierarchia és tisztelet alapvető norma. Azonban a szabályok elárulói, vagy akik a különböző kódexek törvényei ellen vétenek, nem érdemlik meg, és elveszítik az ez iránti lehetőségeiket. Éppen ezért a kivégzések 
módszereinek is ilyennek kell lenniük. A nemzetközi példák arra engednek következtetni, hogy az árulókat általában nem szemből, nem egymás szemébe nézve ölik meg, megadva a lehetőséget, hogy büszkén, emelt fővel viseljék a következményeket, hanem oldalról vagy hátulról likvidálják, hogy érezzék, semmit sem jelentenek, arra sem méltók, hogy „a halállal szembe nézzenek”. Gyakorta üzenetként jelenik meg mindez, és elrettentésül szolgál azoknak, akik véteni kívánnak a búnözői hálózatok írott és íratlan szabályai ellen.

A tanulmányban felállított hipotézis tesztelése nem hozott egzakt és pontos eredményt. A megerősítés kérdéskörében nem tudtuk azt bizonyítani, hogy az emberölés motívuma valóban az árulás indítékaként értelmezhető. A nemzetközi színtéren végbemenő kivégzések és a Cinóber-gyilkosság között olyan hasonlóságok állapíthatók meg, mint az elkövetéshez használt eszköz, az elkövetés napszakbeli időpontja, a halálos bemenetelü lövés jellege, vagy az elkövetés helyszíne, ugyanakkor ez nem elegendő ahhoz, hogy a hipotézisben foglalt „árulói profilt” megalkothassuk. A nemzetközi szakirodalom felhasználhatósága is korlátozottnak bizonyult, hiszen olyan kellő részletességgel az információk nem álltak rendelkezésre, amellyel megnyugtató módon - azaz például korreláció számítására alkalmas módon - az árulói profil és a szervezett bünözéshez köthető kivégzések összehasonlíthatók lettek volna. Ugyan a tanulmány számos a kilencvenes években elkövetett alvilághoz köthető eseménysorozatot megemlít, azok részletes elemzése nem képezi a feldolgozás tárgyát, így azok összehasonlítására a szerzőpáros nem tér ki. (Lásd például, hogy a B. Tamás ellen elkövetett merénylet és kivégzés módszere eszközében eltér a fentiektől, mégis az a rendőri együttmúködésnek köszönhetően árulásként volt értelmezhető.)

A felállított hipotézissel összefüggésben a vizsgálat eredményeként összegezhető, hogy a bizonyítás elvetése mellett a Cinóber-gyilkosság, és a nemzetközi színtéren elkövetett árulással összefüggésbe hozható kivégzések között bizonyos tekintetben hasonlóságok megállapíthatók (lásd fentebb), de azok nem elegendók a hipotézisben foglaltak megerősítésére. Mindez természetesen nem zárja ki egy, már korábbi tanulmányban vizsgált hipotetikus felvetéseket, valamint azok eredményeit, amelyek a D. Ferenc ellen elkövetett emberölést vizsgálták. Javaslatunkat a tekintetben fogalmazzuk meg, hogy a tudományos igényességú vizsgálat további szakirodalom-kutatásra ösztönöz, amely annak sikerességét feltételezve további vizsgálat lefolytatását teheti lehetővé.

A szerzőpáros ismételten fel kívánja hívni a figyelmet arra, hogy az emberöléssel kapcsolatos összevont büntetőeljárás jogi oldala mellett nem kíván sem érvelni, sem ellenérvelni, csupán a szervezett bünözés látens világának egy szeletével ismertette meg az olvasót ebben a tanulmányában.

\section{FELHASZNÁLT IRODALOM}

Alighieri, Dante: Isteni színjáték. Budapest, Akkord, 2009.

Cerami, Adriana Nicole: The Mafia's system of silence in communication, film and literature: Perversions of society and transgressions of Omertà. Chapel Hill, University of North Carolina, 2009. 
KOVÁCS István - TORMA Albert: „Bumm a fejbe...”, avagy kivégzés és leszámolás a kilencvenes években...

Deák József: A Belügyi Szemle és az ideológiai háború Helsinkitől a rendszerváltásig (1975-1990). In Parádi József (szerk): Ünnepi parergák Boda József 65. születésnapja tiszteletére. Budapest, Szemere Bertalan Magyar Rendvédelemtörténeti Tudományos Társaság, 2018. 23-40. Online: https://doi.org/10.31626/HU-EISSN2560094X.IV.TOM.23-40.p

Falcone, Giuseppe: Cose di Cosa Nostra. Rizzoli, 1991.

Garzón, Juan Carlos: The criminal networks in Mexico, Brazil, and Colombia. WWIC, 2008.

Gönczöl Katalin: A bűnözés és a bűnmegelőzés Magyarországon a rendszerváltás időszakában. Magyar Jog, 38. (1991), 11. 646-653.

Gönczöl Katalin: Szegénység és bünözés. INFO-Társadalomtudomány, 5. (1991), 16. 25-30.

Heti Válasz: A magyar szervezett alvilág őstörténete 1-10. Válasz.hu, 2012. Online: https://valasz. hu

Kovács István: „Olajozás”, szervezett bünözés és prostitúció a 90-es években Magyarországon. Nemzetbiztonsági Szemle, 3. (2015), 1. 114-145.

Kovács István: Magyarország határain átnyúló szervezett bűnözés és prostitúciós bűncselekmények a schengeni térségben, különös tekintettel a SOCTA és EUROSTAT értékelésére. Határrendészeti Tanulmányok, 14. (2017), 4. 82-167.

Kovács István: Azok a 90'-es évek: prostitúció és szervezett bünözés, különös tekintettel a „Cinóber” sérelmére elkövetett emberölésre. Magyar Bünüldözö, 11. (2020), 1-2. 100-113.

Mátyás Szabolcs: Magyarország általános bűnözésföldrajzi helyzete. Hadtudományi Szemle, 10. (2017), 4. 497-505.

Pickering-Iazzi, Robin: Dead silent: Life stories of girls and women killed by the Italian mafias, 1878-2018. French, Italian and Comparative Literature Faculty Books, 2019.

Procura Della Repubblica di Palermo: Direzione Distrettuale Antimafia. Verbali di Interrogatorio reso dal collaboratore di giustizia, Leonardo Messina. Judical Document, 1992.

Sifakis, Carl: The Mafia Encyclopedia. New York, Checkmark Books, 2005.

Tondo, Lorenzo: Meet the Sicilian Mafia hitman who killed 80 people and will be free in 5 years. Time, 2015. 10. 21. Online: https://time.com/4062017/sicilian-mafia-hitman/

Truth is stranger than fiction. Total crime: Murderbook 2000-2009. The UK Riots, 2013.

Ürmösné Simon, Gabriella: Organised crime. In Gabriella Ürmösné Simon: Technical English for officers. Budapest, Dialóg Campus, 2018. 87-100.

\section{ABSTRACT}

\section{'Bang in the head...', or Execution and Showdown in the Nineties in an Underworld Way István KOVÁCS - Albert TORMA}

The 1990s were characterised by an uncertain situation in Hungary, which provided a breeding ground for the spread of organised crime. Underworld groups have killed each other, and many cases are still the subject of court proceedings to this day. The series of studies examines with a scientific need whether the murder committed against Ferenc D., known in the underworld circles, was due to the betrayal of the entrepreneur or was driven by other reasons. The study analyses the court judgments and expert opinions of the criminal case of the murder committed against Cinóber, which is compared with the data obtained from mafia accounts in the international arena, assessing the degree of correlation between the two.

Keywords: underworld, the nineties, organised crime, regime change, prostitution 